\title{
Double-Antibody Solid-Phase Radioimmunoassays for Gonadotropins in Serum*
}

\author{
Katsuyoshi SEKI AND Mitsunori SEKI \\ Department of Obstetrics and Gynecology, School of Medicine, \\ Chiba University, Chiba
}

\begin{abstract}
Synopsis
Double-antibody solid-phase (Dasp) method was applied to radioimmunoassays for follicle stimulating hormone (FSH) and luteinizing hormone ( $\mathrm{LH})$ in serum. The Dasp method uses second-antibody immunosorbent for the separation of free and antibody-bound antigen. Several parameters of the assays including concentrations of antiserum and second-antibody immunosorbent, reaction time and temperature were investigated. Reaction with second-antibody immunosorbent required only $2 \mathrm{hr}$ at room temperature both in the FSH and LH assays. Nonspecific binding of labeled hormone to the immunosorbent was negligible. The FSH and $\mathrm{LH}$ assays were specific and sensitive enough to measure $\mathrm{FSH}$ and $\mathrm{LH}$ in serum. In these studies, the Dasp method proved to be useful for quantifying gonadotropins in large numbers of serum samples.
\end{abstract}

A good method of separating free from antibody-bound labeled antigen is essential to the development of radioimmunoassay. Recently, Den Hollander et al. (1972) developed a new separation method using second antiserum coupled to insoluble matrix. This Dasp method was applied to radioimmunoassays for human chorionic gonadotropin (HCG), urinary $\mathrm{FSH}$ and $\mathrm{LH}$, and insulin. In these radioimmunoassays, the Dasp method was proved to be a rapid and versatile separation method. This paper describes the application of the Dasp method to radioimmunoassays for serum gonadotropins.

\section{Materials and Methods}

\section{Hormones for iodination}

Highly purified human pituitary FSH (LER 1366) having 3,014 IU FSH and $213 \mathrm{IU} \cdot \mathrm{LH} / \mathrm{mg}$ and highly

Received for publication February 15, 1973.

* This work was supported in part by Scientific Research Grant 737032 from the Ministry of Education of Japan. purified human pituitary LH (LER 960) containing $923 \mathrm{IU} \mathrm{LH}$ and $1.9 \mathrm{IU} \mathrm{FSH} / \mathrm{mg}$ were kindly supplied by the National Pituitary Agency (NPA), Endocrine Study Section and National Institute of Arthritis and Metabolic Diseases.

\section{Reference preparations}

Human pituitary standard for both FSH and LH (LER 907) having $20 \mathrm{IU}$ FSH and $48 \mathrm{IU} \mathrm{LH} / \mathrm{mg}$ by bioassay was supplied by NPA. Serum levels of FSH and LH were expressed in terms of ng LER $907 / \mathrm{m} l$ of serum. Urinary standard for both FSH and LH (2nd IRP-HMG) was supplied by the Medical Research Council, London. It has 40 IU of both FSH and LH per ampoule.

\section{Antisera}

Antiserum to human pituitary FSH (Batch \#3), Anti-FSH, prepared in rabbits and pre-absorbed with HCG and antiserum to human pituitary LH, AntiLH, prepared in rabbits were supplied by NPA.

\section{Second-antibody immunosorbent}

Gamma-globulin fraction of sheep antiserum to rabbit $\gamma$-globulin coupled to cellulose (Whatman CF 11), Anti-RGG immunosorbent, was kindly supplied by N. V. Organon, Oss, Holland.

HCG

Highly purified HCG containing 12,000 IU/mg 
was kindly donated by Dr. P. Donini, Istituto Farmacologico Serono, Roma. Commercial HCG, Primogonyl (Schering), was also used.

\section{Iodination}

This was carried out by the chloramine- $T$ method of Greenwood et al. (1963). Hormone $(5 \mu \mathrm{g})$ was radioiodinated with ${ }^{125} \mathrm{I}$ to specific activities of 100 to $150 \mu \mathrm{Ci}$ per $\mu \mathrm{g}$. Iodinated hormone was separated from inorganic ${ }^{125} \mathrm{I}$ by passing through a Sephadex G-75 column.

\section{Diluent}

The diluent for labeled hormone, antiserum, immunosorbent, standard and sample was composed of $0.01 \mathrm{M}$ sodium phophate, $0.15 \mathrm{M}$ sodium chloride, $0.025 \mathrm{M}$ EDTA and $0.5 \% \mathrm{BSA}$ at $\mathrm{pH} 7.6$.

\section{Assay procedure}

Labeled hormone $(0.1 \mathrm{ml}, 0.2-0.4 \mathrm{ng})$, antiserum $(0.1 \mathrm{~m} l)$ and sample or standard $(0.2 \mathrm{ml})$ were incubated (1st reaction). Then Anti-RGG immunosorbent $(1 \mathrm{ml})$ was added and the reaction tubes were inverted continuously for a 2nd incubation time. After the completion of the 2 nd reaction, the tubes were centrifuged, the supernatant was aspirated and the precipitate was counted for its radioactivity. The following parameters of the assays were investigated to obtain optimum conditions of the assays: concentrations of antiserum and Anti-RGG immunosorbent, reaction time and temperature.

\section{Results}

\section{FSH radioimmunoassay}

Concentrations of Anti-FSH and Anti-RGG immunosorbent

Anti-FSH was incubated with labeled FSH and $0.2 \mathrm{ml}$ of diluent for $96 \mathrm{hr}$ at $4^{\circ} \mathrm{C}$. Second incubation was performed for $2 \mathrm{hr}$ at room temperature. Effect of the concentrations of Anti-FSH and Anti-RGG immunosorbent on the recovery of the labeled FSH is shown in Figure 1. At a dilution of 1:5,000 of AntiFSH and at dilutions of $1: 5$ through $1: 20$ of Anti-RGG immunosorbent, approximately $35 \%$ of the labeled FSH was recovered in the precipitate. The recovery of the labeled FSH was directly related to the concentration of Anti-FSH. At dilutions of 1:5 through 1:20 of Anti-RGG immunosorbent, the recovery of the labeled FSH was not significantly different,

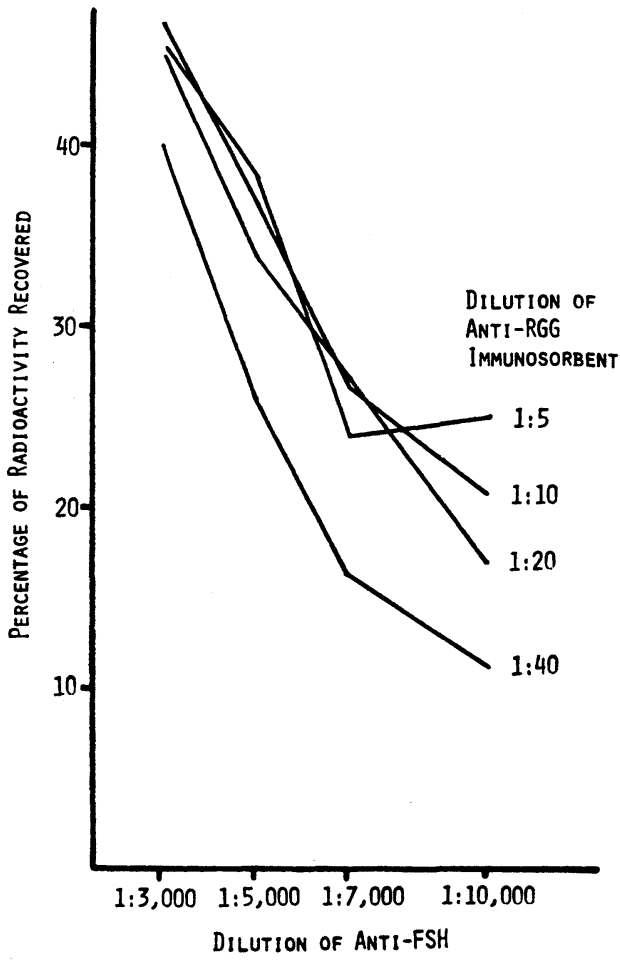

Fig. 1. Effect of dilutions of Anti-FSH and AntiRGG immunosorbent in the FSH assay.

but it decreased at a dilution of 1:40. When Anti-FSH was not added to the assay and Anti-RGG immunosorbent was used at a dilution of $1: 20$, the recovery of the labeled FSH was approximately $1 \%$.

\section{1st incubation time}

When Anti-FSH and Anti-RGG immunosorbent were used at a dilution of $1: 5,000$ and $1: 20$, respectively, and the 2 nd incubation was performed for $2 \mathrm{hr}$ at room temperature, it required $96 \mathrm{hr}$ for the $1 \mathrm{st}$ reation to reach equilibrium both at room temperature and at $4^{\circ} \mathrm{C}$ (Fig. 2).

\section{2nd incubation time}

Anti-FSH and Anti-RGG immunosorbent were used at the same concentration as in the 1st incubation time study and the 1st incubation was performed for $96 \mathrm{hr}$ at $4^{\circ} \mathrm{C}$. The recovery of the labeled FSH reached maximum in $2 \mathrm{hr}$ at room temperature and in $4 \mathrm{hr}$ at $4^{\circ} \mathrm{C}$ (Fig. 3). 


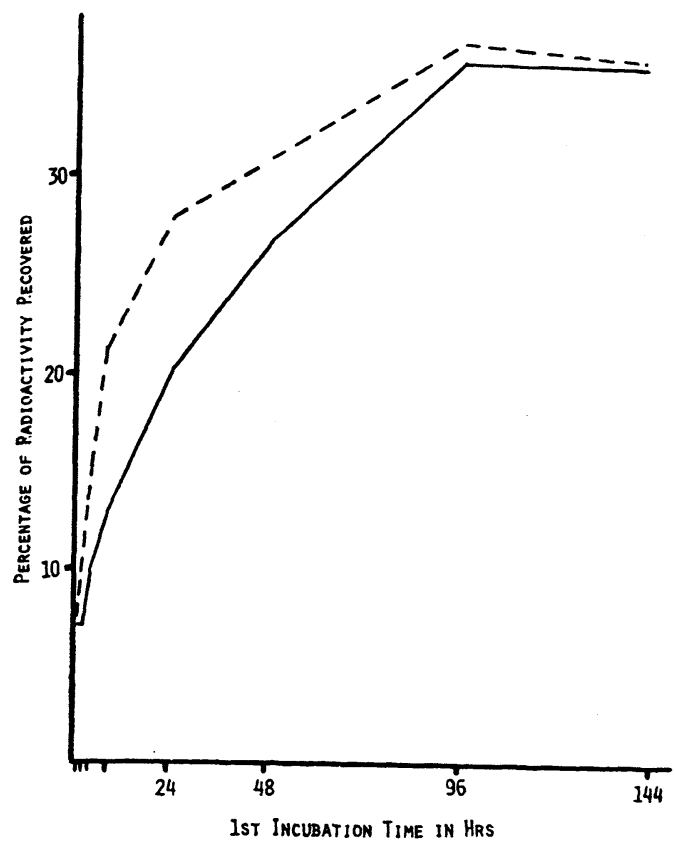

Fig. 2. Effect of 1st incubation time in the FSH assay. The solid line represents 1 st incubation at $4^{\circ} \mathrm{C}$ and the interrupted line, 1st incubation at room temperature.

Based on the above observations, the final form of the FSH assay was determined as follows: concentrations of Anti-FSH and Anti-RGG immunosorbent 1: 5,000 and 1:20, respectively, and 1st incubation, $96 \mathrm{hr}$ at $4{ }^{\circ} \mathrm{C}$ and $2 \mathrm{nd}$ incubation $2 \mathrm{hr}$ at room temperature. Characteristics of the FSH assay

In the above described condition, doseresponse curves of LER 1366, LER 907, 2nd IRP-HMG and serum from a normal woman were parallel (Fig. 4). Purified HCG did not react in the assay, although commercial HCG did. LH cross-reacted in the FSH assay, but the degree of cross-reaction was less than $1 \%$ on a weight basis. Serum from a hypophysectomized patient did not react in the assay. Mean recovery of LER 907 added to serum from a normal man was $102 \%$. Within- and between-assay coefficients of variation were 8 and $10 \%$, respectively. The sensitivity of the assay was $10 \mathrm{ng} / \mathrm{ml}$. In this FSH assay, $1 \mathrm{mg}$

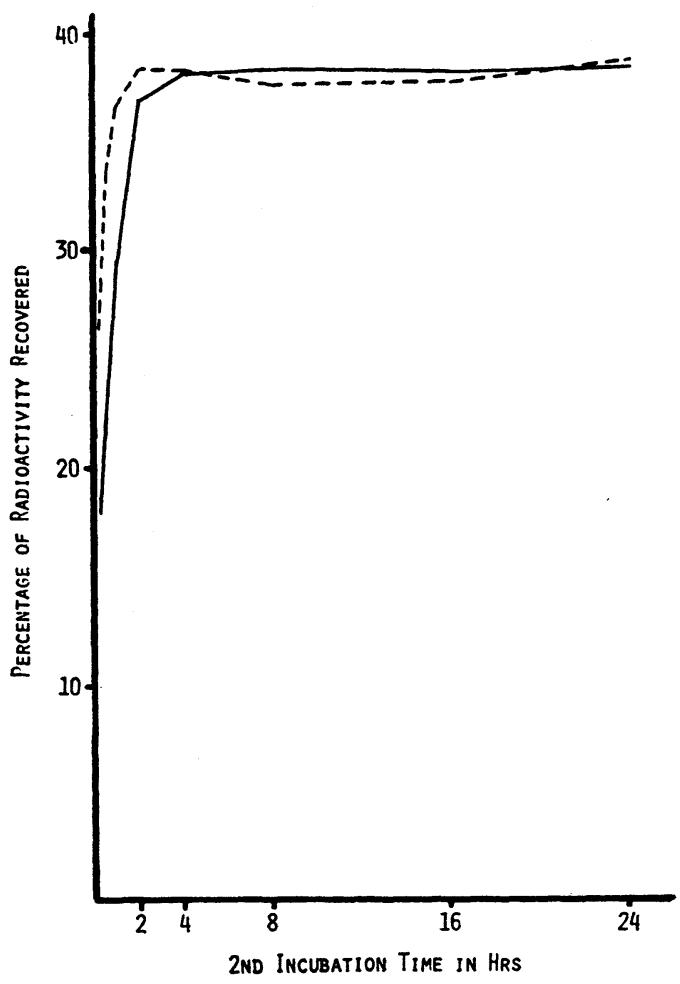

Fig. 3. Effect of 2nd incubation time in the FSH assay. The solid line represents 2 nd incubation at $4^{\circ} \mathrm{C}$ and the interrupted line, 2 nd incubation at room temperature.

of LER 907 was equivalent to 78 IU of 2 nd IRP-HMG.

\section{2. $L H$ radioimmunoassay}

Concentrations of Anti-LH and Anti-RGG immunosorbent

Labeled $\mathrm{LH}$ and $0.2 \mathrm{~m} l$ of diluent were incubated with Anti-LH at various concentrations for $96 \mathrm{hr}$ at $4^{\circ} \mathrm{C}$ and then $1 \mathrm{ml}$ of Anti-RGG immunosorbent was added and the reaction tubes were incubated for further $2 \mathrm{hr}$ at room temperature. At dilutions of 1: 10,000 of Anti-LH and 1: 20 of Anti-RGG immunosorbent, the recovery of the labeled LH was about $30 \%$ (Fig. 5). At dilutions of 1:20,000 and 1:40,000 of Anti-LH, it decreased markedly. The recovery of the labeled LH did not change significantly when Anti- 


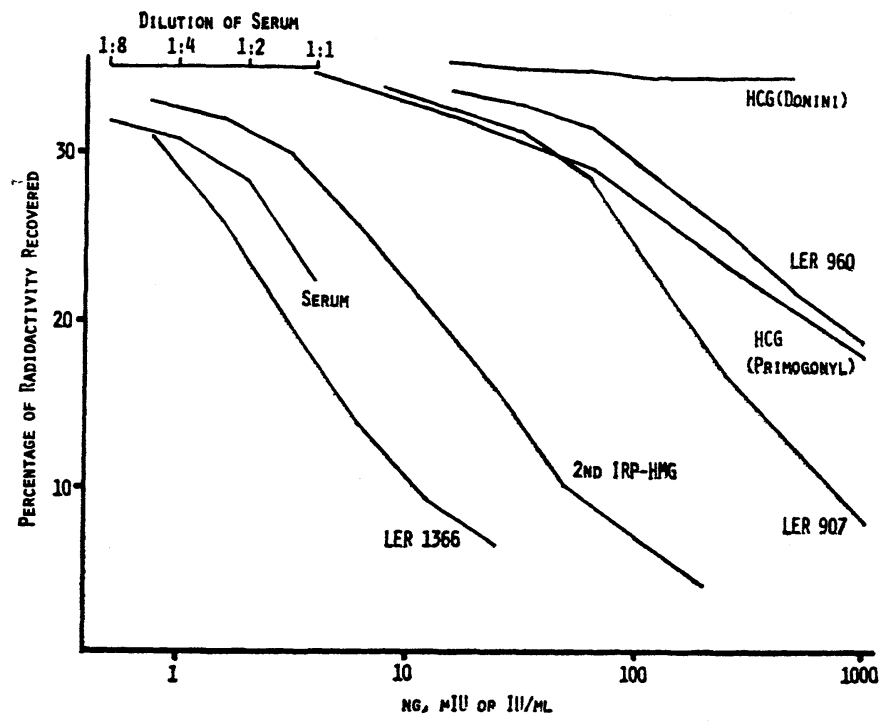

Fig. 4. Dose-response curves for LER 1366, LER 907, LER 960, 2nd IRP-HMG, HCG and serum in the FSH assay. Second IRP-HMG is plotted as $\mathrm{mIU} / \mathrm{m} l, \mathrm{HCG}$ as $\mathrm{IU} / \mathrm{m} l$ and the other hormones are plotted as $\mathrm{ng} / \mathrm{m} l$.

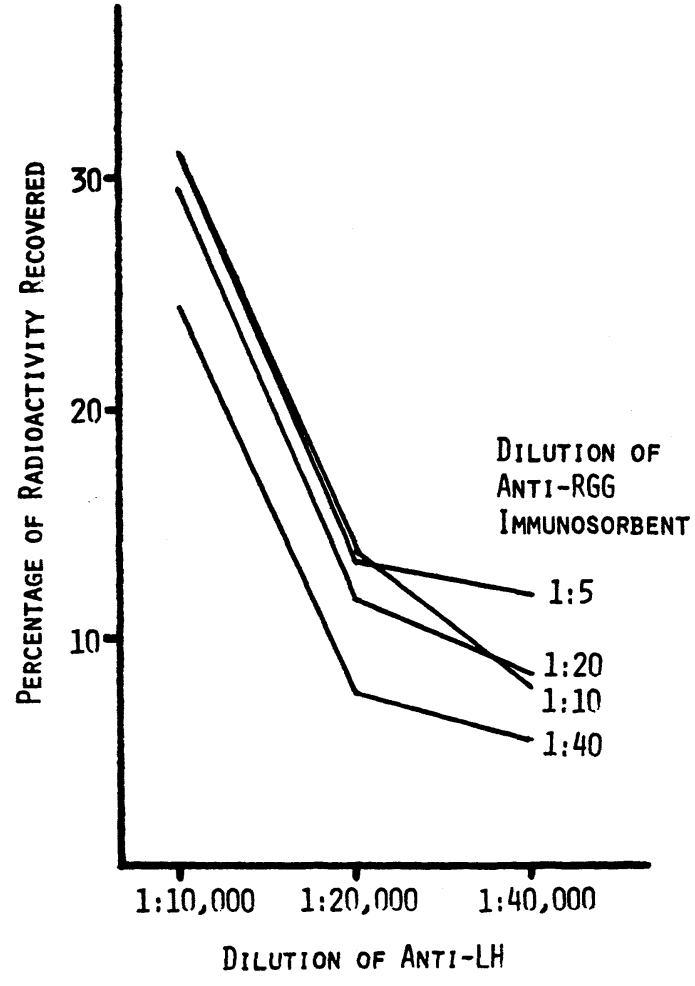

Fig. 5. Effect of dilutions of Anti-LH and AntiRGG immunosorbent in the LH assay.

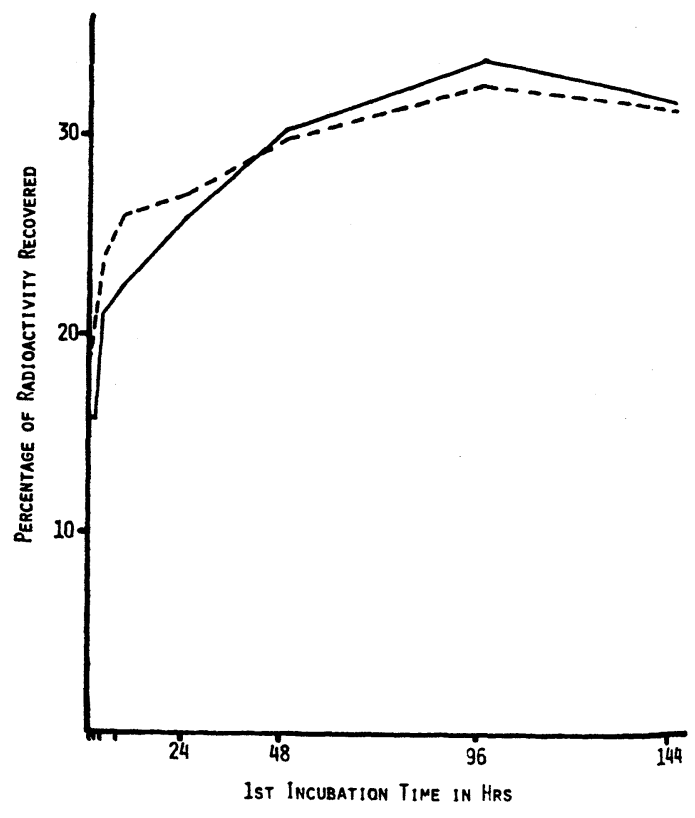

Fig. 6. Effect of 1st incubation time in the LH assay. The solid line represents 1 st incubation at $4^{\circ} \mathrm{C}$ and the interrupted line, 1st incubation at room temperature, 


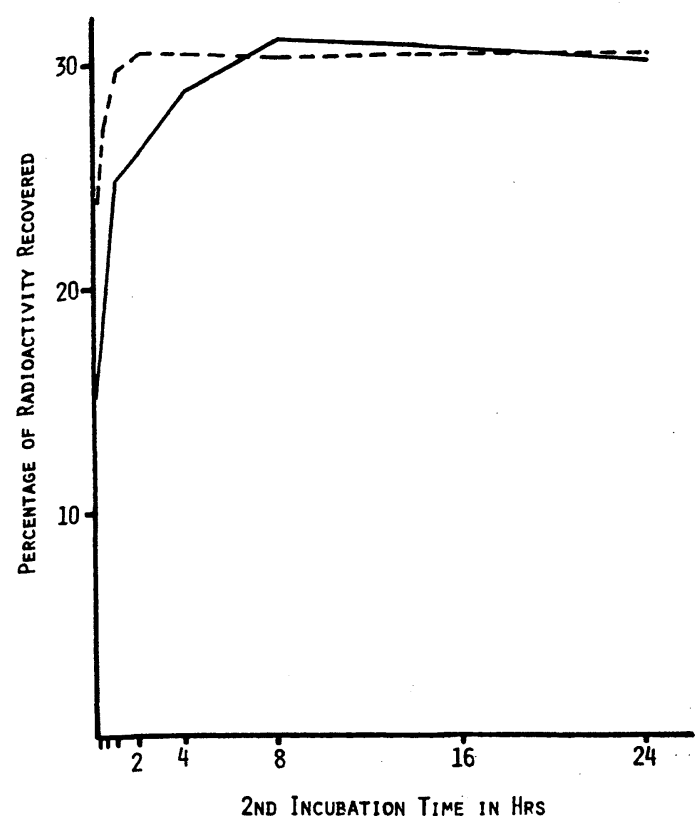

Fig. 7. Effect of 2 nd incubation time in the $\mathbf{L H}$ assay. The solid line represents 2 nd incubation at $4^{\circ} \mathrm{C}$ and the interrupted line, $2 \mathrm{nd}$ incubation at room temperature.

RGG immunosorbent was used at dilutions of 1: 5 through 1:20, but decreased at a dilution of 1:40. Without Anti-LH added to the system, the recovery of the labeled LH was approximately $1 \%$ when Anti-RGG immunosorbent was used at a dilution of 1:20.

Ist incubation time

Labeled LH, Anti-LH $(1: 10,000)$ and $0.2 \mathrm{~m} /$ of diluent were incubated for varying periods at $4{ }^{\circ} \mathrm{C}$ and at room temperature. After the addition of Anti-RGG immunosorbent $(1: 20)$, the reaction was allowed to proceed for further $2 \mathrm{hr}$ at room temperature. First reaction reached equilibrium in $96 \mathrm{hr}$ at $4^{\circ} \mathrm{C}$ and at room temperature (Fig. 6).

2nd incubation time

After labeled $\mathrm{LH}, 0.2 \mathrm{~m} l$ of diluent and Anti-LH $(1: 10,000)$ were incubated for $96 \mathrm{hr}$ at 4 C, Anti-RGG immunosorbent (1:20) was added and the tubes were incubated for varying periods at $4{ }^{\circ} \mathrm{C}$ and at room temperature. The recovery of the labeled $\mathrm{LH}$ was greatest after $2 \mathrm{hr}$ at room temperature and $8 \mathrm{hr}$ at $4^{\circ} \mathrm{C}$ (Fig. 7).

According to the preceding findings, the final form of the $\mathrm{LH}$ assay was set up as follows: concentrations of Anti-LH and Anti-RGG immunosorbent, 1:10,000 and 1: 20 , respectively, 1 st reaction, $96 \mathrm{hr}$ at $4{ }^{\circ} \mathrm{C}$ and 2 nd incubation, $2 \mathrm{hr}$ at room temperature. Characteristics of the $\mathrm{LH}$ assay

In the above conditions, the validity of the LH assay was investigated. LER 960, LER 907, 2nd IRP-HMG and serum from a normal woman gave dose-response curves similar in shape and slope (Fig. 8). FSH (LER 1366) cross-reacted and the degree of cross-reaction was $8 \%$ on a weight basis. LER 907 added to the serum from a normal adult man was recovered quantitatively (mean 104\%). Serum from the hypophysectomized patient did not react in the assay. Within- and betweenassay coefficients of variation were 7 and $14 \%$, respectively. The sensitivity of the assay was $5 \mathrm{ng} / \mathrm{m} /$. In this assay, $1 \mathrm{mg}$ of LER 907 was equivalent to $250 \mathrm{IU}$ of 2 nd IRP-HMG.

\section{Serum FSH and LH levels in women}

Measurements on sera obtained from a normal cycling woman showed mid-cycle peaks of LH and FSH and in addition early follicular phase rise, preovulatory nadir, luteal phase depression and late luteal phase rise of FSH (Fig. 9). FSH and LH levels were also determined in sera obtained from an oligomenorrheic woman during two menstrual cycles, one control cycle and another cycle treated with clomiphene (Clomid). During the control cycle, FSH and LH levels were within normal range but acyclic. Administration of Clomid stimulated an elevation of both FSH and LH during treatment. After a dip, serum LH increased to a peak. In the period of early pregnancy, serum FSH slightly decreased whereas serum LH increased markedly, reflecting large amount of $\mathrm{HCG}$ (Fig. 10).

\section{Discussion}

Although double antibody method is appli- 


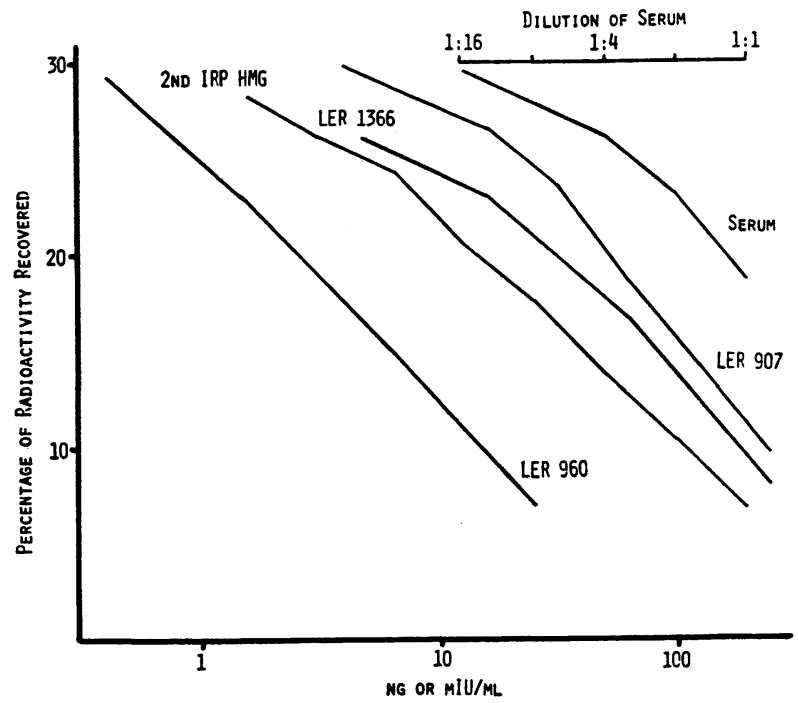

Fig. 8. Dose-response curves for LER 960, LER 907, LER 1366, 2nd IRP-HMG and serum. Second IRP-HMG is plotted as $\mathrm{mIU} / \mathrm{m} l$ and the other hormones as $\mathrm{ng} / \mathrm{m} l$.

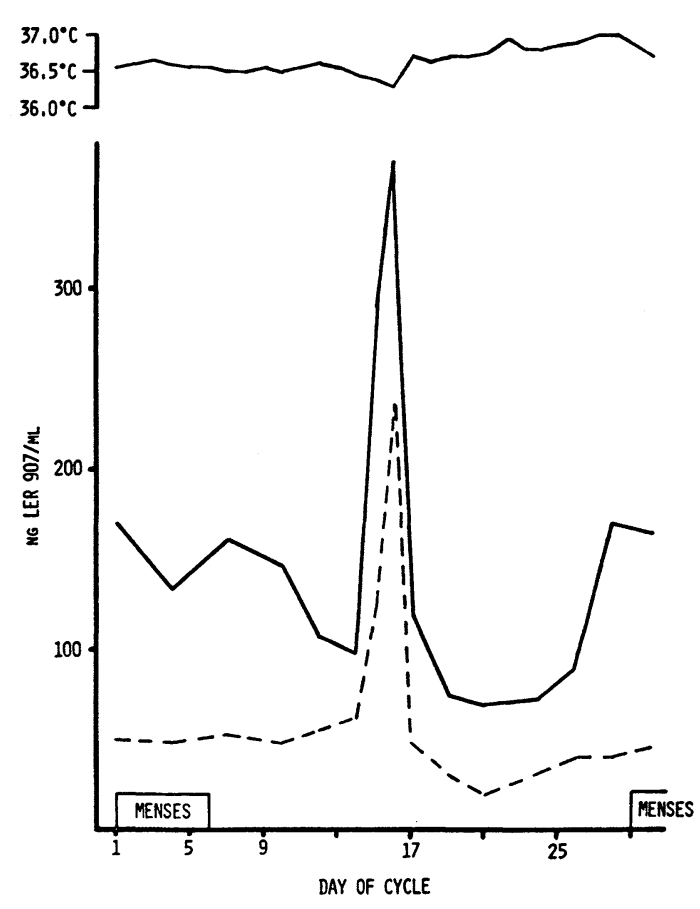

Fig. 9. Serum FSH and LH levels during menstrual cycle.

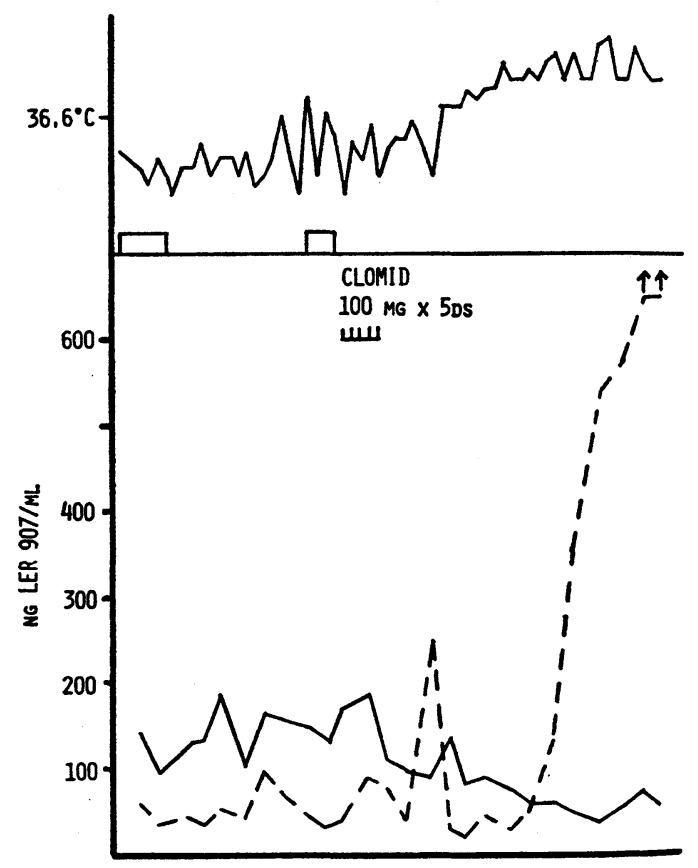

Fig. 10. Serum levels of FSH and LH, their response to Clomid (lower) and basal body temperature (upper) in an oligomenorrheic patient. FSH (solid line) and LH (interrupted line). 
cable to all radioimmunoassay systems, it requires considerable length of time for the immunoprecipitation reaction to reach equilibrium and conditions of the assay must be meticulously evaluated before establishing an assay system. The present Dasp radioimmunoassays for serum $\mathrm{FSH}$ and $\mathrm{LH}$ required only $2 \mathrm{hr}$ for the $2 \mathrm{nd}$ reaction. Both in the FSH and LH assays, the recovery of the labeled hormone was similar when Anti-RGG immunosorbent was used at dilutions of $1: 5$ through 1:20. Thus, the range of suitable dilution of Anti-RGG immunosorbent is wide. Further, the Dasp method does not need carrier protein. The non-specific adsorption of the labeled antigen to the tube wall and to the immunosorbent was prevented by the addition of BSA to the diluent. In the absence of BSA, about $5 \%$ adsorption was found in the HCG radioimmunoassay (Den Hollander et al., 1972). The present FSH and LH radioimmunoassays met most of the criteria required to validate the assay. Although FSH cross-reacted in the LH assay, this crossreaction with FSH is considered to be due to the contamination of $\mathrm{LH}$ in the $\mathrm{FSH}$ preparation used. Serum FSH and $\mathrm{LH}$ levels in a normal cycling woman is similar to the other reported studies including ours (Cargillle et al., 1969; Seki, 1972). Serum FSH depression in early pregnancy is in keeping with the result of Parlow et al. (1970) and provides further evidence for the specificity of the present FSH assay. In conclusion, the Dasp method was rapid, versatile and relatively easy to perform, and proved to be satisfactorily applicable to radioimmunoassays for serum FSH and $\mathrm{LH}$, as previously shown in the radioimmunoassays for urinary $\mathrm{FSH}$ and $\mathrm{LH}$ (Den Hollander et al., 1972).

\section{References}

Cargille, C. M., G. T. Ross and T. Yoshimi (1969). J. Clin. Endocrinol. 29, 12.

Den Hollander, F. C., A. H. W. M. Schuurs and H. Van Hell (1972). J. Immunol. Methods 1, 247.

Greenwood, F. C., W. M. Hunter and J. S. Glover (1963). Biochem. J. 89, 114.

Parlow, A. F., T. A. Daane and W. J. Dignam (1970). J. Clin. Endocrinol. 31, 213.

Seki, K. (1972). Acta Obstet. et Gynaecol. Japon. 19, 25. 